\title{
Extra care housing for people with sight loss: lighting and design
}

Link to publication record in Manchester Research Explorer

\section{Citation for published version (APA):}

Torrington, J., \& Lewis, A. (2011). Extra care housing for people with sight loss: lighting and design. (Research findings). Thomas Pocklington Trust.

\section{Citing this paper}

Please note that where the full-text provided on Manchester Research Explorer is the Author Accepted Manuscript or Proof version this may differ from the final Published version. If citing, it is advised that you check and use the publisher's definitive version.

\section{General rights}

Copyright and moral rights for the publications made accessible in the Research Explorer are retained by the authors and/or other copyright owners and it is a condition of accessing publications that users recognise and abide by the legal requirements associated with these rights.

\section{Takedown policy}

If you believe that this document breaches copyright please refer to the University of Manchester's Takedown Procedures [http://man.ac.uk/04Y6Bo] or contact uml.scholarlycommunications@manchester.ac.uk providing relevant details, so we can investigate your claim.

\section{OPEN ACCESS}




\section{Extra care housing for people with sight loss: lighting and design}

This publication presents findings from research about the design of extra care housing from the perspective of people with sight loss undertaken by Judith Torrington and Alan Lewis, School of Architecture, University of Sheffield.

The study asked 44 people living in 11 extra care housing schemes about their experiences of the buildings they lived in, evaluated their homes and reviewed data from a previous evaluation of 23 extra care housing schemes. The study produced a new tool for evaluating buildings: Evolve-for vision.

\section{Summary findings}

- Buildings that had not been designed specifically for people with sight loss were not very good at supporting those people.

- Natural and artificial lighting levels in lounges and bedrooms were, except for the building designed for people with sight loss, below those recommended for people with low vision.

- Very few buildings gave people the opportunity to control their lighting, e.g. through dimmer switches, use of table and standard lamps, which most people would have appreciated.

- Contrast and colour schemes to assist visual tasks and wayfinding were only used in the building designed for people with sight loss.

- Having a view from their home was valued by all participants: it made people feel connected to life outside.

- Sunlight in their home was welcomed by most participants even if it caused glare or overheating. 


\section{Introduction}

This study examined the design of extra care housing in relation to the needs of people with sight loss. It followed on from the Engineering and Physical Sciences Research Council (EPSRC) funded research which produced the EVOLVE building evaluation tool. The tool is made up of electronic checklists that, when completed, create a profile of how well a building can support residents. They are designed to be used in a walkthrough of a housing scheme. The EVOLVE tool is available on the Housing LIN website at http://www.housinglin.org.uk; search for EVOLVE.

The EPSRC study found that buildings were not very successful at providing sensory support and that lighting levels were relatively low. This raised the question of how well buildings performed for people with low vision and this study investigated that question.

\section{Research objectives and methods}

The objectives of the study were to:

assess whether existing extra care housing schemes complied with design guidance for people with sight loss

- establish whether existing extra care housing schemes meet the needs of people with sight loss

recommend changes or additions to design guidance

- produce a specialist version of the EVOLVE tool that can be used to assess the homes of people with sight loss.

Between October 2010 and May 2011, 44 people with varying types and degrees of sight loss who lived in 11 extra care housing schemes were interviewed about their experiences of the buildings and a detailed survey was carried out of their homes using Evolve-for vision, a new building evaluation tool. Building survey data on 23 extra care housing schemes collected in the earlier EVOLVE study were also used to inform this study. 


\section{Evolve-for vision tool}

Evolve-for vision has a similar structure to the EVOLVE tool. The Evolve-for vision checklists present a series of questions under 12 themes about building design for people with sight loss. Each theme is related to a specific design issue such as 'general lighting' or 'wayfinding'. When the checklists are filled in, the tool calculates a score for each theme and creates a profile of how well a building may support a person with sight loss. The questions and themes in the tool were drawn from literature and design guidance, piloted in three locations and further refined after testing in the homes surveyed in this study. The Evolve-for vision tool is is available on the Housing LIN website at www.housinglin.org.uk and on the research pages of the Pocklington website at http://www.pocklingtontrust.org.uk.

\section{Findings}

Specialist design guidance can lead to housing that makes an important contribution to the ability of people with sight loss to carry out practical tasks and find their way around their homes safely.

The design of extra care housing does not meet the needs of people with sight loss as well as it could. Most schemes do not take account of specialist design guidance for people with low vision, and there is a clear need for those design recommendations to be incorporated into general design guidance. For example: among the 11 schemes surveyed, the apartment lounges in only two schemes had lighting levels above that recommended (200 lux); the rest were lit to only half that level. Among the 11 schemes, one met the recommended lighting levels for bedrooms (150 lux) and one met the recommended level (200 lux) for halls and entrances.

Many communal facilities fell short of daylight levels recommended by the British Standards Lighting Code of Practice: $30 \%$ of communal lounges, $50 \%$ of dining rooms and all six activity rooms in the study fell below recommended levels. 
The majority of the participants placed a high value on having a view from a window even when their ability to see was very limited. A view made people feel connected to life outside. People liked views containing human activity and natural features. Trees in the view were valued because it was possible to deduce weather conditions from the movement of the branches.

- Nearly all participants appreciated sunlight coming into their living unit for part of the day. For some, uncomfortable glare from very high levels of daylight was a problem and indicated the potential value of easily controlled shading devices.

- Issues that affect older people who develop sight loss in later life need to be added to the issues addressed in specialist design guides. As around two in three people with registered sight loss are aged 75 or over this is an important omission. Buildings should - and could - be designed to support the coping strategies that people adopt to compensate for loss of vision, such as using hearing and memory to negotiate environments and relate to other people. Some of these issues will be addressed in the forthcoming 2012 supplement to Pocklington's Design Guide, but more research is needed to address some issues, such as dementia concurrent with sight loss.

Housing design and design guidance should more explicitly recognise that older people with sight loss are likely to have other health conditions which give rise to complex and sometimes conflicting requirements.

Many participants had withdrawn from engagement in activities outside their own homes. Building design that can help people to maintain contact with the outside world and engage in social activity is a matter of clear importance. 


\section{Conclusions}

The overall conclusions from the study were:

The design of extra care housing does not meet the needs of people with sight loss as well as it could. Most schemes do not take account of specialist design guidance for people with sight loss, and there is a clear need for these recommendations to be incorporated into general design guidance.

Specialist design guidance is helpful to people with visual impairment, and can make an important contribution to their ability to carry out everyday tasks in the home and includes

- Housing for People with Sight Loss:

A Thomas Pocklington Trust Design Guide

- Pocklington's Good Practice Guide 4 Housing for People with Sight Loss - a Practical Guide for Improving Existing Homes

- Pocklington's Good Practice Guide 5 Good Housing Design - Lighting

There are, however, issues that specifically affect older people who develop sight loss in later life that are not covered in specialist guides. As the majority of people with sight loss are aged 75 or over, this is a significant omission. Housing should be designed to support the coping strategies people adopt to compensate for loss of vision, such as using hearing and memory to negotiate environments and relate to other people.

- It would also be helpful to highlight design elements explicitly where support needs of people with sight loss conflict with those of people with concurrent conditions, e.g. dementia and hearing loss. Previous research has drawn attention to some of these conflicts and there is a need for further research in this area. More explicit reference to some of these issues in design guidance would be useful in drawing attention to the fact that a universal design solution may not be an attainable goal for a group of people with complex needs. 
- This study has also highlighted that the emotional needs of people with sight loss in terms of their satisfaction with life and their ability to interact socially can be seriously compromised by inadequate building design. This is especially true of people who develop sight loss in old age and who may have other impairments. A more proactive approach to design and management of buildings, particularly with regard to helping people maintain social and recreational activities and maintain contact with the outside world, could make an important additional contribution to the experiences of people with sight loss. Perhaps the most striking aspects of the study were the importance people attached to having a good view from a window and the benefit of daylight and sunlight in their living space. 


\section{Thomas Pocklington Trust}

Housing and support for people with sight loss

Pier House

90 Strand on the Green

London W4 3NN

Tel: 02089950880

Email: info@pocklington-trust.org.uk Web: www.pocklington-trust.org.uk

Published by Thomas Pocklington Trust Registered Charity No. 1113729

Company Registered No. 5359336

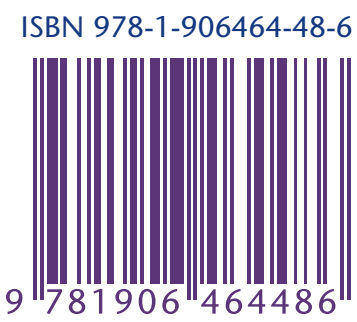

